czym oraz pionierską edycję źródeł z dziejów wychowania rodzinnego.

Kierownik Katedry prowadzi seminarium doktorskie poświęcone dziejom starożytnego Rzymu oraz wychowaniu w starożytności rzymskiej i średniowieczu.

W latach 1977-1994 przygotowano ponad 300 prac magisterskich $\mathrm{z}$ historii wychowania. Przy Katedrze działa Studenckie Koło Historyków Wychowania, a prace jego uczestników, systematycznie, w liczbie już kilkunastu, publikowano w trzech kolejnych „Biuletynach Stu- denckich Kół Naukowych WSP", redagowanych przez J. Jundziłła.

Przedstawiając dorobek naszej dyscypliny w ośrodku bydgoskim, należy dodać, iż badania $z$ zakresu historii wychowania w WSP prowadzone są nie tylko w Katedrze Historii wychowania lecz także przez pracowników Instytutu Historii Wydziału Humanistycznego, przede wszystkim prof. Mariana Pawlaka, ks. prof. Michała Grzybowskiego i dr Bożenę Stawoską-Jundziłk.

Krzysztof Jakubiak

\title{
Materialy źródlowe do badań nad szkolnictwem w Litewskim Państwowym Archiwum Akt Nowych w Wilnie
}

Należy wyrazić wielką radość i podziękowania prof. hab. Marii Kocójowej za opracowanie z zespołem współpracowników i przygotowanie do druku Przewodnika po zbiorach rekkopisów w Wilnie, (Kraków 1993).

Jest to pierwszy przewodnik wydany po 1945 r, który zawiera przegląd zawartości archiwów w Wilnie: Biblioteki Uniwersytetu Wileńskiego, Biblioteki Litewskiej Akademii Nauk, Litewskiej Biblioteki Narodowej, Litewskiego Państwowego Archiwum Historycznego oraz Litewskiego Państwowego Archiwum Akt Nowych. Przejrzysty układ treści Przewodnika, który prezentuje bogate zbiory wymienionych powyżej archiwów wspomaga w znacznej mierze kwerendę archiwalną $\mathrm{i}$ umożliwia szybkie dotarcie do poszukiwanych źródeł.

Mnie, historyka oświaty najbardziej zainteresowały w Przewodniku te pozycje, które odnoszą się do problematyki szkolnictwa, przede wszystkim šrredniego (lata 1918 - 1939) i które znajdują się w Litewskim Państwowym Archiwum Akt Nowych (p. poz. 1504-1561 w Przewodniku).

Korzystając z okazji chciałabym uzupełnić znajdujące się $w$ Przewodniku informacje na temat szkół Okręgu Szkolnego Wileńskiego, gdyż kilkakrotnie już korzystałam z tych materiałów. Niestety nie będą to pelne informacje ponieważ dobór materiałów podyktowany był moimi, konkretnymi zainteresowaniami naukowymi.
W zbiorze Kuratorium Okręgu Szkolnego Wileńskiego - F.172, op. 1 (przyjmuję w dalszej części oznaczenia wileńskie), poz. 1502 Przewodnika, odnotowałam ponad 7600 ponumerowanych teczek zawierających $\mathrm{m}$. in. dokumenty szkół powszechnych (nr 21 -43). Pozostając przy zespole Kuratorium Okręgu Szkolnego Wileńskiego chciałabym zwrócić uwage przede wszystkim na szkoły średnie: gimnazja i seminaria nauczycielskie. Wśród materiałów szkół wymienilabym przede wszystkim księgi protokołów Rady Pedagogicznej, korespondencję szkół z wladzami oświatowymi, sprawozdania z działalności szkół, wykazy uczniów oraz akta personalne nauczycieli. W zespole 172 znajdują się $\mathrm{m}$. in. dokumenty szkół średnich wileńskich, jak: gimnazjów im. E. Orzeszkowej (nr 147, nr 157), im. Zygmunta Augusta (148, 7637), im. Lelewela $(149,159,7628)$, im. Wł. Jagiełly (150) oraz im. J. Śniadeckiego w Oszmianie (153), w Dziśnie (164, 7633, 7634), św. Kazimierza w Nowej Wilejce $(152,161)$, w Baranowiczach (7657), im. Chodkiewicza w Lidzie (7656), im. Mickiewicza w Nowogródku (7658), Matematyczne Gimnazjum Koedukacyjne im. Kościuszki w Słonimie (7654), im. Syrokomli w Nieświeżu (7638), im. Piłsudskiego w Święcianach (166).

Można wskazywać również w omawianym zespole (172) na znaczny zbiór dokumentów dotyczących seminariów nauczycielskich, $\mathrm{m}$. in. w Wilnie ( $\mathrm{nr} 139,140,168,188,361$ ), 
w Nieświeżu (7645, 7661), w Szczuczynie Lidzkim (7659), w Słonimie (7660).

Ponadto można wymienić zebrane akta szkół średnich dla mniejszości narodowych i wyznaniowych, jak: białoruskiego gimnazjum w Radoszkowiczach (146), białoruskiego gimnazjum $w$ Wilnie (672), gimnazjum białorusko-rosyjskiego w Nowogródku (7635), gimnazjum rosyjskiego w Wilnie $(163,576)$, w Dziśnie (164), gimnazjów żydowskich: Zrzeszenia Nauczycieli $(557,566,567)$, Stowarzyszenia Pedagogów (569).

Dokumenty poszczególnych szkół znajdują się również w odrębnie numerowanych zbiorach. I tak: Państwowe Gimnazjum im. J. Lelewela 7.X.1915-1938, F.184 (p. poz. 1505 Przewodnik), op. 1 (1915-1937), zawiera m. in. okólniki (teczki nr 7-8), protokoły posiedzeń Rady Pedagogicznej (14, 54 -55), księgi protokolów Rady Pedagogicznej (60, 78, 103, 122 , 206). Natomiast op.2 (1919 - 1938) stanowią m. in. akta osobowe nauczycieli gimnazjum (nr 280 - 386).

Państwowe Gimnazjum i Liceum im. Zygmunta Augusta w Wilnie 27. VIII. 1917-1939, F.180 (p. poz. 1506 Przewodnik), op. 1 (1917 - 1939) obejmuje $\mathrm{m}$. in. protokoły Rady Pedagogicznej $(6,18,46$ - 47, 80 - 81, 129 - 130, $150,163,255,449$ ) oraz korespondencję w sprawach nauczycieli $(21,24,66,133$ - 134).

Państwowe Gimnazjum im. T. Czackiego w Wilnie 15. IX. 1926 - 1934, F.182 (p. poz. 1520 Przewodnik). Z op. 1 wynotowałam księgi protokolów Rady Pedagogicznej z lat 1926, 1929-1930, 1932 (nr 1, 5, 8, 15).

Ze zbiorów Państwowego Gimnazjum im. św. Kazimierza w Nowej Wilejce 6. IX 1922-1939, F.204 (p. poz. 1558 Przewodnik) korzystałam z korespondencji KOS, op.2 1922 - 1941 (nr 77, 80 - 82, 84-85, 93-96). W dokumentach Państwowego Gimnazjum im. A. Mickiewicza w Wilnie VIII. 1922-1940, F.178 (p. poz. 1509 Przewodnik) zainteresowały mnie przede wszystkim akta personalne nauczycieli, op. 1 1922-1939, nr 195-305.

Podobnie wśród żródeł Państwowego Seminarium Nauczycielskiego Męskiego im. Tomasza Zana w Wilnie 27. X. 1919 - 15. VI. 1936, F.219 (p. poz. 1544 Przewodnik), op. 11919 - 1936 wybrałam akta osobowe personelu szkoły (nr 809 - 921). Ponadto tematyke kad- ry pedagogicznej zawierają teczki nr 29 i 146. Teczka nr 292 zawiera korespondencję w sprawie likwidacji seminarium nauczycielskiego w Borunach (1936/37).

Wykazy nauczycieli, spisy oraz akta personalne znajdują się również $w$ zespołach innych szkół średnich: np. Gimnazjum Humanistyczne Koedukacyjne Ety Dzięcielskiej w Wilnie 19.V.1921 - 3.VII.1933, F.196 (p. poz. 1538 Przewodnik) op. $1 \mathrm{nr}$ 26, 28, 62, 70, 81, 207 - 244; Prywatne Koedukacyjne Żydowskie Gimnazjum Chaima Wygodzkiego 4.IX.1927 - 1931 (p. poz. 1540 Przewodnik - figuruje pod nazwa $\mathrm{Ch}$. Wygodzkiej), op. 1, nr 2.

Gimnazjum Koedukacyjne Towarzystwa Pedagogicznego 23.VII.1919-1939, F.202 (p. poz. 1541 Przewodnik, gdzie figuruje pod nazwa Gimnazjum Humanistyczne Żydowskiego Centralnego Komitetu Oświaty), op. 1, 1919 - 1939, nr 897-937.

Prywatne Gimnazjum Żeńskie SS Nazaretanek 3.X.1915 - 20.VI.1940, F.192 (p. poz. 1512 Przewodnik), op. 1, 1915 - 1940, nr 138, 140, 150, $316-317,346-347$.

Jako uzupełnienie podanych informacji w Przewodniku chciałabym podać nazwy zespołów (i sygnatury) tych szkół, które nie znalazhy się w wymienionym opracowaniu:

- II Państwowe Gimnazjum i Liceum im. E. Plater w Grodnie 1926-1938, F.1138;

- Białoruskie gimnazjum w Klecku 1924 - 1931, F.207;

- Litewskie gimnazjum 1918 - 1939, F.212;

- Prywatne gimnazjum litewskie 1919, F.1127.

W Przewodniku pozycje 1532 i 1533 oznaczone sq numerem zespołu 183 i słusznie ale Gimnazjum Żeńskie L. Pospielowej umieszczone jest $w$ op. 1, natomiast Gimnazjum im. A. Puszkina - op. 2 i 2a. Z kolei pozycje 1515 i 1512 (F.187) dotyczą Wileńskiego Gimnazjum i koedukacyjnych kursów dla dorosłych. Wymienione kursy dla dorosłych zostały przekształcone w gimnazjum dla młodzieży.

Myślę, że przekazane w powyższym komunikacie fragmentaryczne informacje na temat zbiorów archiwalnych pozwola środowisku historyków oświaty na dokładniejsze zapoznanie się ze źródlami dotyczącymi szkolnictwa polskiego i dla mniejszości narodowych w latach 1917- 1940.

Stefania Walasek 